\title{
Modified-Release Calcifediol Effectively Controls Secondary Hyperparathyroidism Associated with Vitamin D Insufficiency in Chronic Kidney Disease
}

\author{
Stuart M. Sprague ${ }^{a}$ Arnold L. Silva ${ }^{b}$ Fahd Al-Saghirc Radhika Damle ${ }^{d}$ \\ Samir P. Tabash ${ }^{d}$ Martin Petkovich ${ }^{\mathrm{e}}$ Eric J. Messner ${ }^{d}$ Jay A. White ${ }^{d}$ \\ Joel Z. Melnick ${ }^{d}$ Charles W. Bishop ${ }^{d}$ \\ a NorthShore University Health System-University of Chicago, Pritzker School of Medicine, Evanston, III., \\ ${ }^{b}$ Boise Kidney \& Hypertension Institute, Meridian, Idaho, 'Michigan Kidney Consultants, Pontiac, Mich., \\ ${ }^{\mathrm{d}}$ OPKO Health, Inc., Miami, Fla., USA; ${ }^{\mathrm{e}}$ Queen's University, Kingston, Ont., Canada
}

\section{Key Words \\ Chronic kidney disease (CKD) · Secondary \\ hyperparathyroidism (SHPT) · Vitamin D · Vitamin D insufficiency - Calcifediol (25-hydroxyvitamin $\mathrm{D}_{3}$ ) · Calcitriol (1,25-dihydroxyvitamin $\left.\mathrm{D}_{3}\right) \cdot$ Parathyroid hormone (PTH)}

\begin{abstract}
Background/Aims: Vitamin D insufficiency drives secondary hyperparathyroidism (SHPT) and is associated with increased cardiovascular mortality in patients with chronic kidney disease (CKD). SHPT is poorly addressed by current vitamin D repletion options. The present study evaluated a novel investigational vitamin $D$ repletion therapy: a modified-release (MR) formulation of calcifediol designed to raise serum 25 -hydroxyvitamin $D$ in a gradual manner to minimize the induction of CYP24 and, thereby, improve the SHPT control. Methods: This randomized, double-blind, placebo-controlled trial evaluated MR calcifediol in CKD subjects $(n=78)$ with plasma intact parathyroid hormone (iPTH) $>70 \mathrm{pg} / \mathrm{ml}$ and serum total 25 -hydroxyvitamin $D<30 \mathrm{ng} / \mathrm{ml}$. Subjects received daily treatment for six weeks with oral MR calcifediol $(30,60$ or $90 \mu \mathrm{g})$ or a placebo. Results: More than $90 \%$ of subjects treated with MR calcifediol achieved serum 25-hydroxyvitamin D levels $\geq 30 \mathrm{ng} / \mathrm{ml}$ versus $3 \%$ of subjects treat-
\end{abstract}

ed with placebo $(p<0.0001)$. Mean plasma iPTH decreased from baseline $(140.3 \mathrm{pg} / \mathrm{ml})$ by $20.9 \pm 6.2 \%$ (SE), $32.8 \pm 5.7$ and $39.3 \pm 4.3 \%$ in the 30,60 and $90 \mu \mathrm{g}$ dose groups, respectively, and increased $17.2 \pm 7.8 \%$ in the pooled placebo group ( $p<0.005)$. No clinically significant safety concerns arose during MR calcifediol treatment. Conclusion: Oral MR calcifediol appears safe and highly effective in treating SHPT associated with vitamin D insufficiency in CKD.

(C) 2015 S. Karger AG, Basel

\section{Introduction}

Vitamin D insufficiency afflicts more than 20 million adults in the United States (US) having stage 1 through 4 chronic kidney disease (CKD) [1]. The prevalence of vitamin D insufficiency increases with CKD severity and is associated with low serum total 1,25-dihydroxyvitamin $\mathrm{D}$, secondary hyperparathyroidism (SHPT) and metabolic bone disease, suggesting that vitamin D insufficiency has a causal role in these related disorders $[2,3]$.

Multiple factors drive vitamin D insufficiency in CKD including nutritional inadequacy, decreased sunlight exposure, proteinuric loss and decreased hepatic synthesis of 25-hydroxyvitamin $\mathrm{D}$, and increased expression of

\section{KARGER}

E-Mail karger@karger.com

www.karger.com/ajn
(C) 2015 S. Karger AG, Basel

0250-8095/15/0406-0535\$39.50/0
Stuart M. Sprague, DO

Division of Nephrology and Hypertension

NorthShore University Health System

2650 North Ridge Avenue, Evanston, IL 60201 (USA)

E-Mail SSprague@ northshore.org 
CYP24, the cytochrome P-450 enzyme that specifically catabolizes vitamin D and its metabolites [4-6]. Adequate production of 1,25-dihydroxyvitamin $\mathrm{D}$ by renal and extra-renal 1a-hydroxylase (CYP27B1) requires sufficient 25 -hydroxyvitamin D supply. Consequently, vitamin D insufficiency can cause reduced vitamin $\mathrm{D}$ hormone production and its sequelae of decreased intestinal absorption of dietary calcium $(\mathrm{Ca})$, increased secretion of parathyroid hormone (PTH), and metabolic bone disease. Inadequate 1,25 -dihydroxyvitamin $\mathrm{D}$ production is exacerbated by increased fibroblast growth factor 23 (FGF23), which causes progressive decreases in renal CYP27B1 activity with advancing CKD $[7,8]$.

The K/DOQI and KDIGO Clinical Practice Guidelines for the treatment of metabolic bone disease in CKD recommend regular screening for elevated PTH beginning in stage 3 CKD $[9,10]$. They also recommend testing for vitamin D insufficiency as soon as elevated PTH is encountered, and correcting it with oral ergocalciferol or cholecalciferol supplementation. Consensus is lacking on the definition of vitamin D insufficiency with K/DOQI, for example, defining it as $<30 \mathrm{ng} / \mathrm{ml}$ and the Institute of Medicine (IOM) favoring $<20 \mathrm{ng} / \mathrm{ml}$ [11]. Supplementation with vitamin $\mathrm{D}$ has been found to be inconsistently effective and often inadequate in patients with predialysis CKD, leaving SHPT largely uncorrected [12]. Thus, therapy with vitamin $\mathrm{D}$ receptor activators (VDRAs) is required to treat SHPT in many predialysis CKD patients. Although VDRAs lower plasma PTH, they also can raise FGF23 and CYP24-mediated vitamin D catabolism, as evidenced by elevated 24,25-dihydroxyvitamin D [13]. Clearly, improved vitamin D repletion therapy is needed.

An overlooked vitamin D repletion therapy is calcifediol (25-hydroxyvitamin $\mathrm{D}_{3}$ ). Oral calcifediol was approved in the United States in 1980 for the treatment for metabolic bone disease in dialysis patients and was withdrawn from the market in 2001-2002 for commercial reasons; it was displaced by VDRAs. Calcifediol is more readily absorbed in the intestine than ergocalciferol or cholecalciferol due to its increased polarity and resulting lack of reliance on adequate bile secretion [14-16]. Many clinical studies have shown that immediate-release (IR) calcifediol boosts serum 25-hydroxyvitamin D more effectively than ergocalciferol or cholecalciferol [17-19]. However, IR calcifediol produces only clinically meaningful reductions in $\mathrm{PTH}$ ( $230 \%$ from pre-treatment levels) in CKD patients when administered at doses that raise serum 25-hydroxyvitamin D to supra-physiological levels $(>100 \mathrm{ng} / \mathrm{ml})[20,21]$. High doses of IR calcifediol cause surges in serum 1,25-dihydroxyvitamin D which, in turn, induce the expression of CYP24 in target tissues such as the parathyroid glands, attenuating the desired inhibition of PTH secretion [22].

The present study evaluated a modified-release (MR) formulation of calcifediol, designed to raise serum 25-hydroxyvitamin $\mathrm{D}$ in a gradual manner to physiological levels $(\geq 30$ to $\leq 100 \mathrm{ng} / \mathrm{ml})$, avoiding excessive induction of CYP24. In this study, the efficacy and safety of a 6-week course of daily MR calcifediol was compared to placebo in elevating serum 25 -hydroxyvitamin $\mathrm{D}$ to $\geq 30 \mathrm{ng} / \mathrm{ml}$ (adequacy) and in reducing elevated plasma intact PTH (iPTH) in predialysis CKD patients with SHPT and vitamin D insufficiency.

\section{Methods}

\section{Study Design}

This randomized, double-blind, placebo-controlled trial involved 78 subjects recruited from 16 US sites into two cohorts studied sequentially. Subjects in each cohort were randomized to 6 weeks of daily treatment with either MR calcifediol or a matching placebo, followed by 6 weeks of post-treatment monitoring. In Cohort 1 , a total of 51 subjects were assigned to three treatment groups $(\mathrm{n}=17)$ receiving MR calcifediol $(60$ or $90 \mu \mathrm{g})$ or placebo. In Cohort 2, 27 subjects were assigned to two treatment groups receiving $30 \mu \mathrm{g}$ of $\mathrm{MR}$ calcifediol $(\mathrm{n}=13)$ or placebo $(\mathrm{n}=14)$. Plasma iPTH and serum Ca, phosphorus (P), calcifediol, total 25-dihydroxyvitamin $\mathrm{D}$ and total 1,25-dihydroxyvitamin $\mathrm{D}$ were measured weekly. Routine blood chemistries, hematologic parameters, fasting spot urine $\mathrm{Ca}$ and creatinine $(\mathrm{Cr})$ levels, and serum FGF23, bone-specific alkaline phosphatase (BAP), C-reactive protein (CRP) and bone natriuretic protein (BNP) were measured monthly. An independent Data Safety Monitoring Board (DSMB) monitored patient safety throughout the study. The primary efficacy endpoints were the proportion of subjects that achieved (a) serum 25-hydroxyvitamin D levels of $\geq 30 \mathrm{ng} / \mathrm{ml}$ and (b) mean percent reductions of plasma iPTH of $\geq 30 \%$ from pre-treatment baseline at the end of treatment (EOT).

\section{Subject Selection}

Eligible subjects had ages between 18 and 85 (inclusive) and $\mathrm{CKD}$ (not requiring regular dialysis) as evidenced by an estimated glomerular filtration rate (eGFR) of $\geq 25$ and $<70 \mathrm{ml} / \mathrm{min} / 1.73 \mathrm{~m}^{2}$. Other eligibility criteria included serum total 25 -hydroxyvitamin $\mathrm{D}$ between 10 and $29 \mathrm{ng} / \mathrm{ml}$ (inclusive), plasma iPTH above 70 $\mathrm{pg} / \mathrm{ml}$, serum Ca of $\geq 8.4$ to $<10.0 \mathrm{mg} / \mathrm{dl}$ and serum $\mathrm{P}$ of $\geq 2.0$ to $<5.0$ $\mathrm{mg} / \mathrm{dl}$. Exclusion criteria included spot urine $\mathrm{Ca}$ :Cr ratio $>0.2$, nephrotic range proteinuria ( $>3 \mathrm{mg} / \mathrm{mg} \mathrm{Cr}$ ), and history of parathyroidectomy or renal transplantation. Subjects taking more than $1,000 \mathrm{mg} /$ day of elemental Ca reduced their intake for the duration of the study and underwent a 14-day pre-treatment washout. Subjects receiving supplementation with ergocalciferol or cholecalciferol maintained a stable dose below 1,600 IU/day. Any bone metabolism therapy (with the exception of bisphosphonates) that could potentially interfere with study endpoints was discontinued for the duration of the study and a 28-day pre-treatment washout 
was imposed. In the case of bisphosphonates, subjects had to be on a stable dose for $>6$ months prior to enrollment and maintain that dose for study duration.

Drug Products and Dosing

Calcifediol was purchased from the Dishman Group (Veenendaal, the Netherlands) and formulated in MR capsules containing 30, 60 or $90 \mu \mathrm{g}$ by Catalent Pharma Solutions (Clearwater, Fla., USA). The capsules gradually released calcifediol over a 12-hour period during in vitro dissolution testing. Placebo capsules had the same formulation except for the omission of calcifediol. Subjects were instructed to take one capsule by mouth every day at bedtime (with liquid). Subjects discontinued dosing if they had confirmed plasma iPTH $<30 \mathrm{pg} / \mathrm{ml}$, serum Ca $>10.5 \mathrm{mg} / \mathrm{dl}$, serum $\mathrm{p}>5.5 \mathrm{mg} / \mathrm{dl}$ (only if deemed to be study drug related), or serum 25 -hydroxyvitamin D >100 ng/ml.

\section{Subject Disposition}

Nine subjects terminated study participation prematurely: 2 withdrew consent ( 1 each in the placebo and $30 \mu \mathrm{g}$ groups); 2 experienced an adverse event requiring study termination ( 1 in the placebo group and 1 in the $90 \mu$ group); 3 reached laboratory safety parameters ( 1 in the $60 \mu \mathrm{g}$ group exhibited serum Ca of 10.6 to $10.7 \mathrm{mg} / \mathrm{dl}, 1$ in the $90 \mu \mathrm{g}$ group developed serum 25 -hydroxyvitamin $\mathrm{D}>100 \mathrm{ng} / \mathrm{ml}$, and 1 in the $90 \mu \mathrm{g}$ group exhibited plasma iPTH $<30 \mathrm{pg} / \mathrm{ml}$ ); and 2 were lost to follow-up (both in the $90 \mu \mathrm{g}$ group). Four of these subjects terminated during the post-treatment observation period.

\section{Laboratory and Clinical Procedures}

Blood samples were shipped for analysis to SpectraEast Laboratory (Rockleigh, N.J., USA). Plasma iPTH levels were determined by two-site sandwich immunochemiluminescence. Serum total 25-hydroxyvitamin D and 1,25-dihydroxyvitamin D, BAP and BNP were determined by chemiluminescence. CRP was analyzed using a turbidometric assay. Serum samples were forwarded to PharmaNet (Quebec City, Que., Canada) for analysis of calcifediol by high-performance liquid chromatography with tandem mass spectrometry detection, and to Queens University (Kingston, Ont., Canada) for analysis of intact FGF23 by ELISA (Immunotopics, San Clemente, Calif., USA). A 12-lead electrocardiogram (ECG) and the Beck Depression Inventory Questionnaire [23] were obtained from each subject prior to and after the 6-week treatment period.

\section{Analysis of Data}

Serum Ca values were corrected for albumin below $4.0 \mathrm{~g} / \mathrm{dl}$. eGFR was calculated with the Modification of Diet in Renal Disease (MDRD) equation [24]. Pre-treatment 'baseline' values for all parameters were defined as the average of three determinations obtained at (a) the two latest screening visits and (b) prior to dosing on the day that treatment was initiated. EOT values were defined as the average of three determinations obtained at $\sim 12 \mathrm{~h}$ after the last administered dose in the 5 th week of treatment and at $\sim 12$ and $\sim 36 \mathrm{~h}$ after the last administered dose in the 6 th week of treatment. Efficacy endpoints were analyzed in the intent-to-treat (ITT) and per-protocol (PP) populations, but results of only the PP analyses are reported herein, since there were no material differences between the two analyses. The PP population was defined as the 73 subjects who completed the 6-week treatment period.

Modified-Release Calcifediol Suppresses $\mathrm{PTH}$ in $\mathrm{CKD}$
The pharmacokinetic (PK) parameters for baseline-corrected serum calcifediol and total 1,25-dihydroxyvitamin $\mathrm{D}$ were derived using non-compartmental analysis. Area under the serum concentration-time curve (AUC) was estimated using the linear trapezoid rule. The $t_{1 / 2}$ was calculated by determination of the elimination rate constant from concentration values in the follow-up period.

\section{Results}

\section{Study Population}

Demographic and baseline characteristics of the 78 randomized subjects are summarized in table 1, by treatment group. No significant differences in these characteristics were detected between the two placebo groups, or between the pooled placebo group and any of the three active treatment groups. No significant differences were observed among the treatment groups for prior or concomitant medications. Key baseline and EOT characteristics of the 73 subjects comprising the PP population are shown in table 2 .

\section{Serum Total 25-Hydroxyvitamin D}

The mean baseline 25-hydroxyvitamin $\mathrm{D}$ for all 78 subjects was $21.3 \mathrm{ng} / \mathrm{ml}$. The 6 -week course of daily MR calcifediol effectively treated vitamin D insufficiency as more than $90 \%$ of subjects in the 30,60 and $90 \mu \mathrm{g}$ dose groups achieved adequate serum 25 -hydroxyvitamin D levels ( $\geq 30 \mathrm{ng} / \mathrm{ml}$ ) by EOT compared with only $3 \%$ in the pooled placebo group $(\mathrm{p}<0.0001)$. Daily MR calcifediol increased mean serum 25-hydroxyvitamin D approximately in proportion to the administered dose (fig. 1). The 30 and $90 \mu \mathrm{g}$ doses increased mean serum 25-hydroxyvitamin $\mathrm{D}$ at EOT to $37.3 \pm 2.0(\mathrm{SE}) \mathrm{ng} / \mathrm{ml}$ and to $84.8 \pm 5.5 \mathrm{ng} / \mathrm{ml}$, respectively. A mean decrease of $1.9 \pm$ $0.7 \mathrm{ng} / \mathrm{ml}$ was observed in the pooled placebo group. Differences between the three MR calcifediol groups and the placebo group were all significant $(\mathrm{p}<0.0001)$.

\section{Serum Calcifediol}

Mean serum calcifediol concentrations gradually increased during treatment in a dose-dependent fashion and then decreased thereafter (fig. 2). Mean peak concentrations (Cmax), after adjustment for baseline values, were $27.8 \pm 2.4(\mathrm{SE}), 60.3 \pm 4.7$ and $85.7 \pm 7.2 \mathrm{ng} / \mathrm{ml}$ for the 30, 60 and $90 \mu$ g groups, respectively. Calcifediol exposures, calculated as mean background adjusted areaunder-the-curve (AUC 0-6 weeks), were dose proportional and the median terminal elimination half-life $\left(t_{1 / 2}\right)$ was 24 to 36 days. Linear regression analyses of slopes between each 2 consecutive PK time points indicated that 
Table 1. Subject demographic and baseline characteristics (all randomized subjects)

\begin{tabular}{|c|c|c|c|c|c|c|c|c|}
\hline \multirow[t]{2}{*}{ Characteristic } & \multicolumn{3}{|l|}{ Placebo } & \multicolumn{4}{|c|}{ MR calcifediol } & \multirow{2}{*}{$\begin{array}{l}\text { Total } \\
(\mathrm{n}=78)\end{array}$} \\
\hline & $\begin{array}{l}\text { Cohort } 1 \\
(\mathrm{n}=17)\end{array}$ & $\begin{array}{l}\text { Cohort } 2 \\
(\mathrm{n}=14)\end{array}$ & $\begin{array}{l}\text { Total } \\
(\mathrm{n}=31)\end{array}$ & $\begin{array}{l}30 \mu \mathrm{g} \\
(\mathrm{n}=13)\end{array}$ & $\begin{array}{l}60 \mu \mathrm{g} \\
(\mathrm{n}=17)\end{array}$ & $\begin{array}{l}90 \mu \mathrm{g} \\
(\mathrm{n}=17)\end{array}$ & $\begin{array}{l}\text { Total } \\
(\mathrm{n}=47)\end{array}$ & \\
\hline \multicolumn{9}{|l|}{ Sex } \\
\hline Female & $13(76.5)$ & $7(50.0)$ & $20(64.5)$ & $7(53.8)$ & $7(41.2)$ & $9(52.9)$ & $23(48.9)$ & $43(55.1)$ \\
\hline Male & $4(23.5)$ & $7(50.0)$ & $11(35.5)$ & $6(46.2)$ & $10(58.8)$ & $8(47.1)$ & $24(51.1)$ & $35(44.9)$ \\
\hline \multicolumn{9}{|l|}{ Race } \\
\hline White & $10(58.8)$ & $6(42.9)$ & $16(51.6)$ & $8(61.5)$ & $14(82.4)$ & $10(58.8)$ & $32(68.1)$ & $48(61.5)$ \\
\hline Black or African-American & $7(41.2)$ & $8(57.1)$ & $15(48.4)$ & $4(30.8)$ & $3(17.6)$ & $7(41.2)$ & $14(29.8)$ & $29(37.2)$ \\
\hline Other & 0 & 0 & 0 & $1(7.7)$ & 0 & 0 & $1(2.1)$ & $1(1.3)$ \\
\hline \multicolumn{9}{|l|}{ Ethnicity } \\
\hline Hispanic or Latino & $2(11.8)$ & $1(7.1)$ & $3(9.7)$ & $2(15.4)$ & $2(11.8)$ & $1(5.9)$ & $5(10.6)$ & $8(10.3)$ \\
\hline Not Hispanic or Latino & $15(88.2)$ & $13(92.9)$ & $28(90.3)$ & $11(84.6)$ & $15(88.2)$ & $16(94.1)$ & $42(89.4)$ & $70(89.7)$ \\
\hline Age, years & $61.9 \pm 17.79$ & $63.9 \pm 11.47$ & $62.8 \pm 15.06$ & $58.2 \pm 16.14$ & $64.7 \pm 9.20$ & $65.4 \pm 11.41$ & $63.1 \pm 12.34$ & $63.0(13.39)$ \\
\hline BMI, $\mathrm{kg} / \mathrm{m}^{2}$ & $35.2 \pm 7.63$ & $32.0 \pm 7.73$ & $33.7 \pm 7.73$ & $33.5 \pm 8.76$ & $35.5 \pm 6.74$ & $36.7 \pm 6.84$ & $35.4 \pm 7.33$ & $34.7(7.48)$ \\
\hline $\mathrm{Ca}, \mathrm{mg} / \mathrm{dl}$ & $9.4 \pm 0.31$ & $9.4 \pm 0.31$ & $9.4 \pm 0.31$ & $9.3 \pm 0.44$ & $9.3 \pm 0.36$ & $9.3 \pm 0.30$ & $9.3 \pm 0.36$ & $9.3(0.34)$ \\
\hline $\mathrm{P}, \mathrm{mg} / \mathrm{dl}$ & $3.6 \pm 0.43$ & $3.4 \pm 0.48$ & $3.5 \pm 0.46$ & $3.8 \pm 0.55$ & $3.5 \pm 0.58$ & $3.8 \pm 0.52$ & $3.7 \pm 0.55$ & $3.6(0.52)$ \\
\hline iPTH, pg/ml & $160.6 \pm 65.90$ & $127.6 \pm 69.04$ & $145.7 \pm 68.27$ & $150.8 \pm 58.87$ & $115.3 \pm 28.30$ & $147.4 \pm 58.56$ & $136.7 \pm 51.41$ & $140.3(58.44)$ \\
\hline $\mathrm{eGFR}, \mathrm{ml} / \mathrm{min} / 1.73 \mathrm{~m}^{2}$ & $36.9 \pm 14.04$ & $40.9 \pm 11.37$ & $38.7 \pm 12.86$ & $36.7 \pm 11.00$ & $42.6 \pm 9.13$ & $37.2 \pm 10.22$ & $39.5 \pm 9.80$ & $39.2(11.04)$ \\
\hline 25-hydroxyvitamin $\mathrm{D}, \mathrm{ng} / \mathrm{ml}$ & $18.9 \pm 5.49$ & $20.6 \pm 5.50$ & $19.7 \pm 5.47$ & $21.7 \pm 6.56$ & $23.4 \pm 4.52$ & $21.8 \pm 4.81$ & $22.3 \pm 5.20$ & $21.3(5.43)$ \\
\hline 1,25-dihydroxyvitamin $\mathrm{D}, \mathrm{pg} / \mathrm{ml}$ & $23.4 \pm 12.20$ & $22.7 \pm 12.55$ & $23.1 \pm 12.16$ & $18.8 \pm 7.70$ & $21.7 \pm 7.02$ & $20.9 \pm 7.81$ & $20.6 \pm 7.43$ & $21.6(9.60)$ \\
\hline
\end{tabular}

Values are presented as $\mathrm{n}(\%)$ or mean $\pm \mathrm{SD}$.

Table 2. Subject end of treatment characteristics (per protocol subjects)

\begin{tabular}{|c|c|c|c|c|c|c|c|}
\hline Characteristic & \multicolumn{3}{|l|}{ Placebo } & \multicolumn{4}{|l|}{ MR calcifediol } \\
\hline \multicolumn{8}{|l|}{ Baseline } \\
\hline $\mathrm{Ca}, \mathrm{mg} / \mathrm{dl}$ & $9.4 \pm 0.31$ & $9.4 \pm 0.31$ & $9.4 \pm 0.31$ & $9.3 \pm 0.46$ & $9.3 \pm 0.34$ & $9.3 \pm 0.33$ & $9.3 \pm 0.37$ \\
\hline $\mathrm{P}, \mathrm{mg} / \mathrm{dl}$ & $3.6 \pm 0.43$ & $3.4 \pm 0.48$ & $3.5 \pm 0.46$ & $3.8 \pm 0.58$ & $3.6 \pm 0.58$ & $3.8 \pm 0.55$ & $3.7 \pm 0.57$ \\
\hline $\mathrm{Ca} /$ Creatinine, $\mathrm{mg} / \mathrm{g}$ & $22.7 \pm 25.75$ & $29.2 \pm 20.03$ & $25.5 \pm 23.29$ & $19.6 \pm 12.59$ & $40.8 \pm 39.80$ & $38.3 \pm 46.44$ & $34.1 \pm 37.57$ \\
\hline FGF23, pg/ml & $22.2 \pm 12.29$ & $20.6 \pm 13.05$ & $21.5 \pm 12.45$ & $37.5 \pm 30.33$ & $23.8 \pm 16.18$ & $28.8 \pm 18.07$ & $29.4 \pm 21.85$ \\
\hline $\mathrm{eGFR}, \mathrm{ml} / \mathrm{min} / 1.73 \mathrm{~m}^{2}$ & $36.9 \pm 14.04$ & $40.9 \pm 11.37$ & $38.7 \pm 12.86$ & $35.6 \pm 10.69$ & $42.6 \pm 9.42$ & $36.0 \pm 10.59$ & $38.9 \pm 10.01$ \\
\hline \multicolumn{8}{|l|}{ End-of-treatment } \\
\hline $\mathrm{Ca}, \mathrm{mg} / \mathrm{dl}$ & $9.4 \pm 0.40$ & $9.4 \pm 0.28$ & $9.4 \pm 0.35$ & $9.4 \pm 0.45$ & $9.4 \pm 0.33$ & $9.4 \pm 0.29$ & $9.4 \pm 0.35^{\mathrm{a}}$ \\
\hline $\mathrm{P}, \mathrm{mg} / \mathrm{dl}$ & $3.7 \pm 0.54$ & $3.5 \pm 0.54$ & $3.6 \pm 0.55$ & $4.0 \pm 0.74$ & $3.9 \pm 0.78$ & $4.0 \pm 0.63$ & $4.0 \pm 0.70$ \\
\hline FGF23, pg/ml & $28.7 \pm 23.35$ & $24.5 \pm 33.56$ & $26.8 \pm 27.99$ & $36.9 \pm 26.31$ & $27.9 \pm 14.60$ & $36.6 \pm 24.92$ & $33.4 \pm 22.28$ \\
\hline $\mathrm{eGFR}, \mathrm{ml} / \mathrm{min} / 1.73 \mathrm{~m}^{2}$ & $36.7 \pm 12.82$ & $41.1 \pm 12.15$ & $38.7 \pm 12.52$ & $36.1 \pm 13.08$ & $37.8 \pm 10.24$ & $37.3 \pm 11.39$ & $37.2 \pm 11.22$ \\
\hline
\end{tabular}

End of treatment (EOT) values were compared to baseline values using a mixed effect model: ${ }^{\mathrm{a}} \mathrm{p}<0.05 ;{ }^{\mathrm{b}} \mathrm{p}<0.001 ;{ }^{\mathrm{c}} \mathrm{p}<0.0001$. Values are mean $\pm \mathrm{SD}$. 


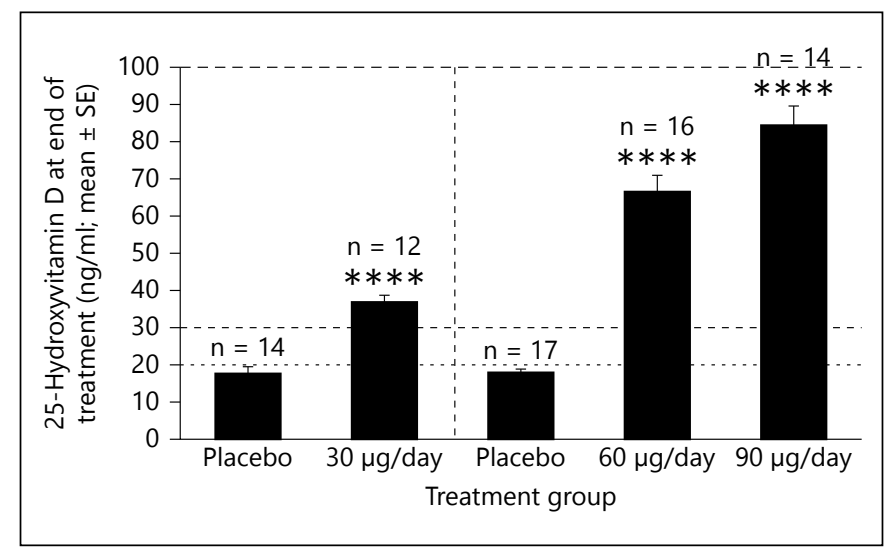

Fig. 1. Changes in serum 25-hydroxyvitamin D. Serum total 25-hydroxyvitamin $\mathrm{D}(\mathrm{ng} / \mathrm{ml})$ at the end of the 6-week treatment period increased approximately in proportion to the administered dose $(30,60$ or $90 \mu \mathrm{g} /$ day) in all groups receiving MR calcifediol and relative to the placebo groups, with all differences between each active and corresponding placebo group reaching significance. The three horizontal dashed lines indicate the lower limit of normal per the IOM (fine) and K/DOQI (medium), and the upper limit of the laboratory reference range (coarse). **** Significantly different from placebo, $\mathrm{p}<0.0001$.

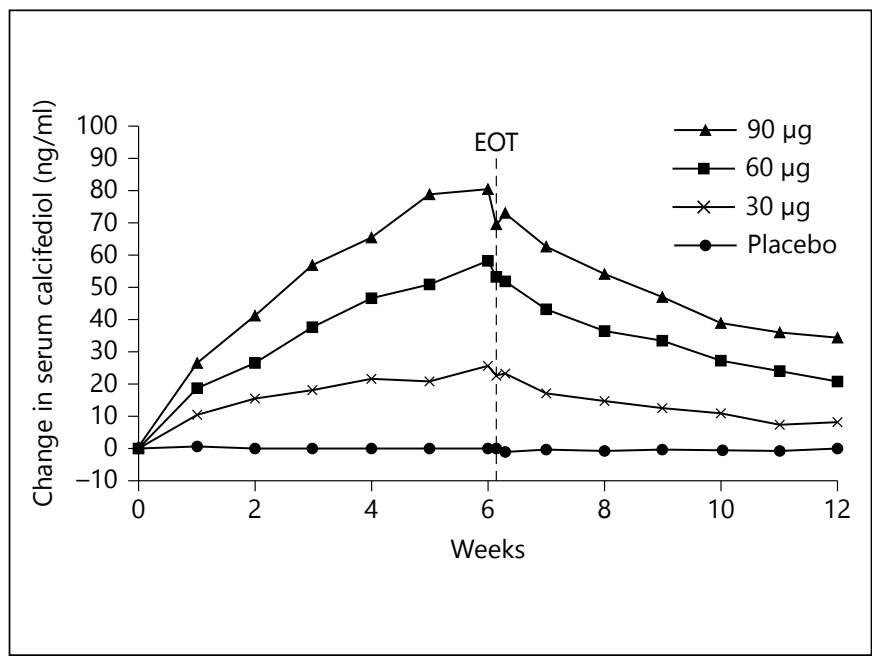

Fig. 2. Changes in calcifediol (25-hydroxyvitamin $\left.\mathrm{D}_{3}\right)$. Serum calcifediol concentrations $(\mathrm{ng} / \mathrm{ml})$ gradually increased during the 6 -week treatment period from pre-treatment baseline in proportion to the administered dose (30,60 or $90 \mu \mathrm{g}$ /day) in all groups receiving $\mathrm{MR}$ calcifediol, and declined after the end of treatment (EOT). Plotted values have been corrected for differences in baseline.
Fig. 3. Changes in plasma iPTH. Percent changes in plasma iPTH at the end of the 6-week treatment period from pre-treatment baseline were negative and approximately proportional to the administered dose $(30,60$ or $90 \mu \mathrm{g} /$ day) in all groups receiving MR calcifediol and positive in the placebo groups, with differences between each active and corresponding placebo group reaching significance. ${ }^{*}$ Significantly different from placebo, $\mathrm{p}<0.05$; ${ }^{* *}$ Significantly different from placebo, $\mathrm{p}<0.001$.

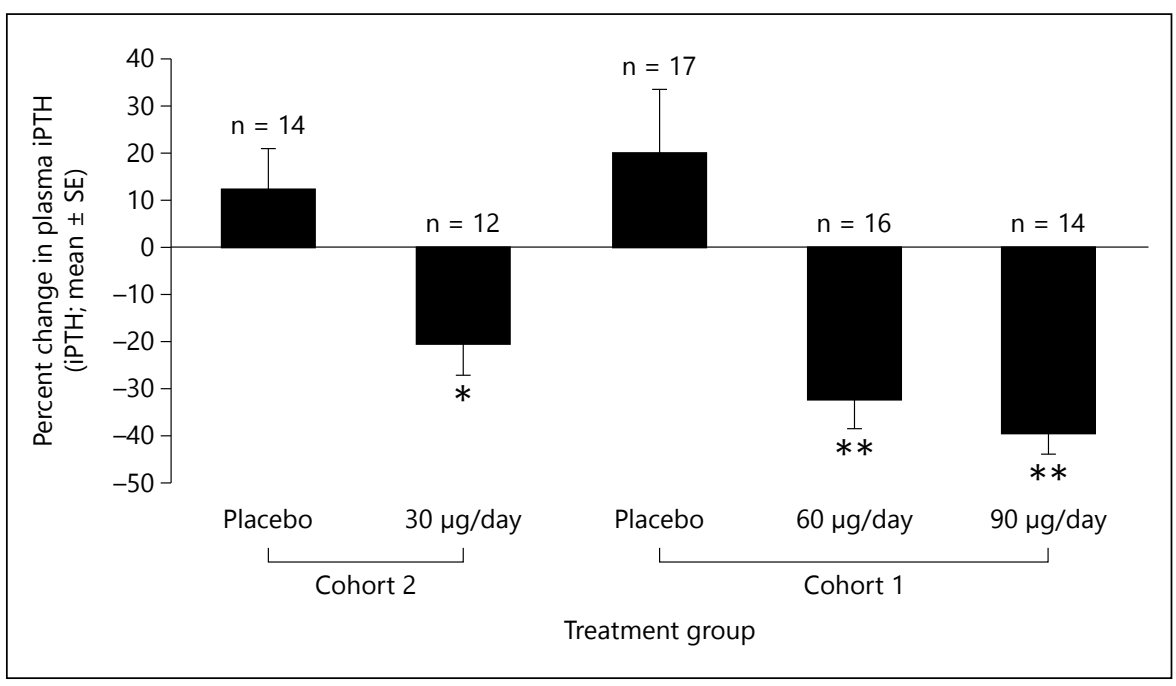

steady state levels of calcifediol would have been achieved after 8 to 9 weeks of dosing. Racial differences in serum calcifediol levels at EOT were not detected.

\section{Plasma iPTH}

Mean baseline iPTH concentration for the study population was $140.3 \mathrm{pg} / \mathrm{ml}$. Daily MR calcifediol therapy progressively reduced the mean iPTH from baseline approx- imately in proportion to the administered dose (fig. 3). The mean percent changes from baseline at EOT were $-20.9 \pm 6.2 \%$ (SE), $-32.8 \pm 5.7 \%$ and $-39.3 \pm 4.3 \%$ for the 30,60 and $90 \mu \mathrm{g}$ dose groups, respectively, compared to $+17.2 \pm 7.8$ in the pooled placebo group $(\mathrm{p}<0.005)$. The proportion of subjects treated with MR calcifediol who achieved a mean reduction of at least $20 \%$ increased progressively with dose reaching $93 \%$ in the $90 \mu$ g group, and 
Fig. 4. Response rates for plasma iPTH reduction. The portion of subjects attaining a reduction in plasma iPTH of at least 20 or $30 \%$ is shown for three groups receiving MR calcifediol (30, 60 or $90 \mu \mathrm{g} /$ day) and the pooled placebo group, with significance noted for differences between active and placebo treatment. * Significantly different from placebo, $\mathrm{p}<0.05$; ${ }^{* *}$ Significantly different from placebo, $\mathrm{p}<0.01$; $* * *$ Significantly different from placebo, $\mathrm{p}<0.001$; $* * * *$ Significantly different from placebo, $\mathrm{p}<0.0001$.

Fig. 5. Changes in serum calcium and phosphorus. Weekly corrected serum $\mathrm{Ca}$ and serum $\mathrm{P}$ values $(\mathrm{mg} / \mathrm{dl})$ from the intent-to-treat population are shown for the 6-week treatment period for groups receiving 30, 60 or $90 \mu \mathrm{g} /$ day of MR calcifediol and for the pooled placebo group. Data at week 0 represent pre-treatment baseline values. Serum Ca values are shown in black and are plotted according to the scale on the left axis; serum $P$ values are shown in gray and are plotted according to the scale on the right axis. Significant differences from baseline are indicated.
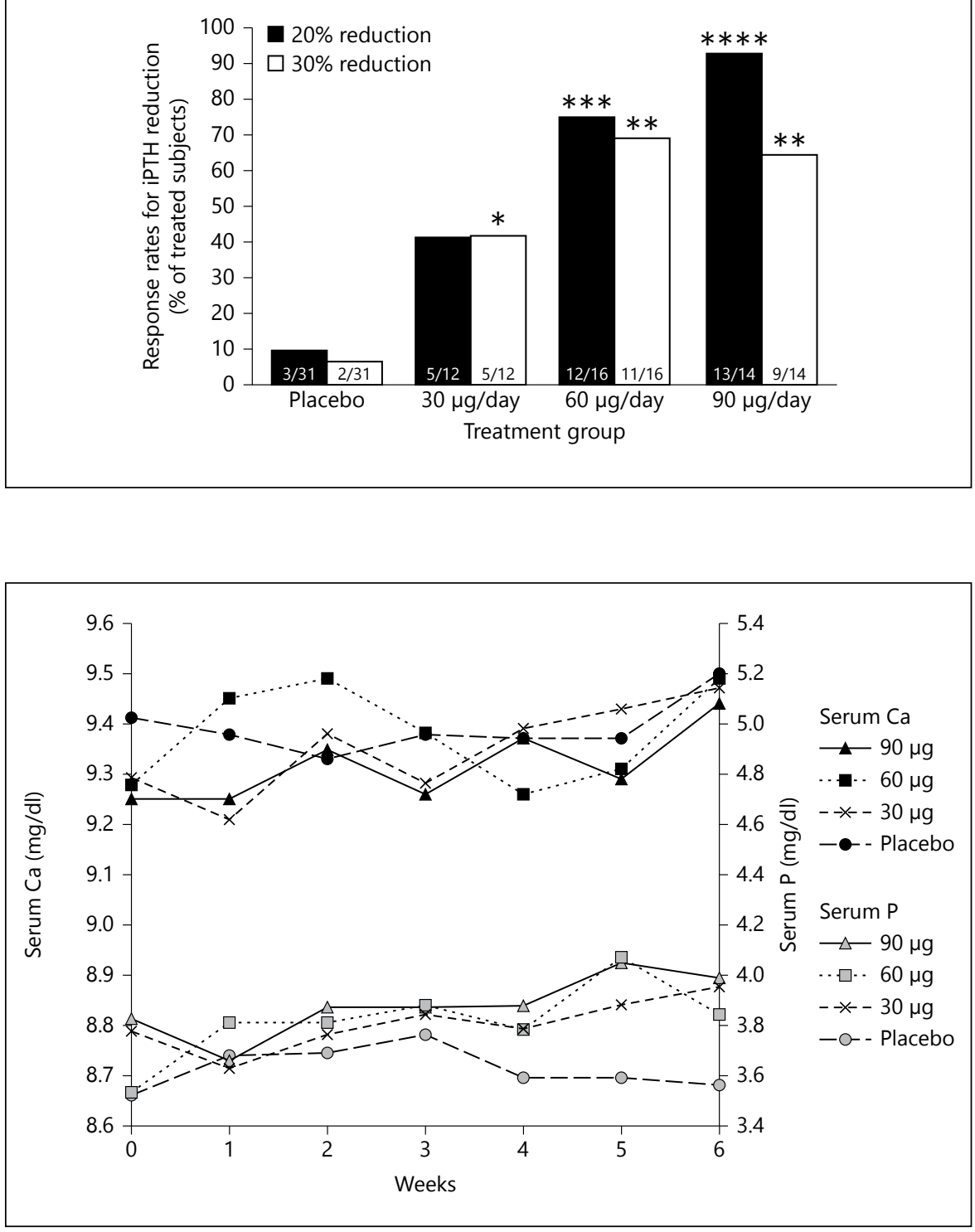

the proportion of subjects who achieved a reduction of $30 \%$ increased with dose to $64-69 \%$ (fig. 4). Differences in the observed response rates for a mean 30\% iPTH reduction were significant between all $3 \mathrm{MR}$ calcifediol groups and the corresponding placebo groups $(\mathrm{p}<0.05)$. Racial differences in $\mathrm{PPTH}$ reduction at EOT were not detected.

\section{Serum $C a$ and $P$, and Urine $C a$}

Mean serum $\mathrm{Ca}$ and $\mathrm{P}$ concentrations during the 6-week treatment period are shown in figure 5 . The only change reaching statistical significance occurred in the 60 $\mu \mathrm{g}$ group where mean serum Ca rose from a baseline value of $9.3 \pm 0.09$ (SE) to a week 6 value of $9.5 \pm 0.11$ (p <
0.05 ). The EOT value for the 60 ug group (average of 3 determinations including the week 6 value) was unchanged from baseline (see table 2). The change in mean serum Ca from baseline to EOT $(\sim 0.1 \mathrm{mg} / \mathrm{dl})$ in all subjects treated with MR calcifediol was significant $(\mathrm{p}<$ 0.05 ). No differences were detected between treatment groups regarding changes in urinary $\mathrm{Ca}$ excretion, expressed as a ratio to $\mathrm{Cr}$ excretion, from baseline ( $\mathrm{p}>$ 0.05 ). One instance of hypercalcemia (confirmed serum $\mathrm{Ca}>10.5 \mathrm{mg} / \mathrm{dl}$ ) was observed in one subject in the $60 \mu \mathrm{g}$ group. Hyperphosphatemia (confirmed serum $\mathrm{P}>5.5$ $\mathrm{mg} / \mathrm{dl}$ related to study drug administration) and hypercalciuria (>200 mg Ca/g Cr) were not observed. 
Fig. 6. Changes in serum total 1,25-dihydroxyvitamin D. Serum 1,25-dihydroxyvitamin $\mathrm{D}(\mathrm{pg} / \mathrm{ml})$ showed gradual increases during the 6-week treatment period from pre-treatment baseline in all groups receiving MR calcifediol. Plotted values have been corrected for differences in baseline.

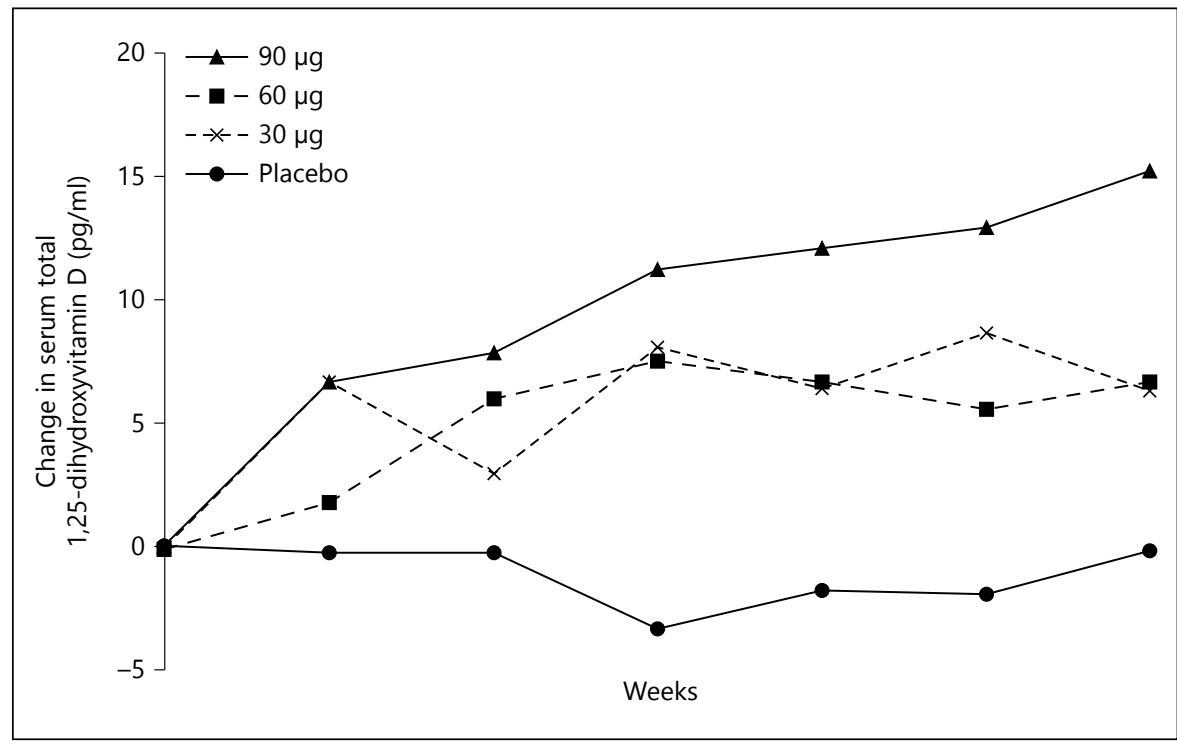

Table 3. Overall summary of treatment-emergent adverse events (all randomized subjects)

\begin{tabular}{|c|c|c|c|c|c|}
\hline \multirow[t]{2}{*}{ Characteristic } & \multirow{2}{*}{$\begin{array}{l}\text { Placebo } \\
(\mathrm{n}=31)\end{array}$} & \multicolumn{4}{|c|}{ MR calcifediol } \\
\hline & & $\begin{array}{l}30 \mu g \\
(n=13)\end{array}$ & $\begin{array}{l}60 \mu g \\
(n=17)\end{array}$ & $\begin{array}{l}90 \mu \mathrm{g} \\
(\mathrm{n}=17)\end{array}$ & $\begin{array}{l}\text { Total } \\
(\mathrm{n}=47)\end{array}$ \\
\hline Subjects with no TEAE & $8(25.8)$ & $4(30.8)$ & $5(29.4)$ & $6(35.03)$ & $15(31.9)$ \\
\hline Subjects with at least one TEAE & $23(74.2)$ & $9(69.2)$ & $12(70.6)$ & $11(64.7)$ & $32(68.1)$ \\
\hline Subjects with related TEAE & $6(19.4)$ & $3(23.1)$ & $4(23.5)$ & $5(29.4)$ & $12(25.5)$ \\
\hline Subjects with severe TEAE & $1(3.2)$ & $0(0.0)$ & $1(5.9)$ & $1(5.9)$ & $2(4.3)$ \\
\hline Subjects with serious TEAE & $1(3.2)$ & $1(7.7)$ & $1(5.9)$ & $1(5.9)$ & $3(6.4)$ \\
\hline Subjects discontinued due to TEAE & $1(3.2)$ & $0(0.0)$ & $0(0.0)$ & $1(5.9)$ & $1(2.1)$ \\
\hline
\end{tabular}

\section{Serum Total 1,25-Dihydroxyvitamin D}

Mean baseline-adjusted serum total 1,25-dihydroxyvitamin D concentrations gradually increased with daily MR calcifediol during the 6-week treatment period (fig. 6). No change was observed in subjects administered placebo. Differences in exposure (AUC 0-6 weeks) to serum 1,25-dihydroxyvitamin $\mathrm{D}$ between all groups receiving MR calcifediol and placebo were significant $(\mathrm{p}<$ 0.05).

\section{Other Parameters}

No significant changes from baseline or differences between treatment groups were observed at the end of the 6-week treatment period for eGFR, serum FGF23, BNP, $\mathrm{BAP}$, or CRP, hematology and coagulation parameters, vital signs, ECG evaluations, or the Beck Depression Inventory II.

\section{Adverse Events}

No deaths occurred during the study, no serious adverse events were deemed related to study drug, and no significant differences were observed between the MR calcifediol and placebo groups regarding nonserious adverse events attributed to study drug. Overall, comparable proportions of subjects reported treatment-emergent adverse events (TEAEs) across the treatment groups (table 3). A TEAE was defined as any adverse event, regardless of relationship to study drug, which occurred during or after receiving study drug. No dose-dependent patterns were observed with the exception that more subjects in the $90 \mu \mathrm{g}$ group reported gout $(\mathrm{n}=4,23.5 \%)$, which was considered unrelated to study drug. Two of these 4 subjects reported gout before starting treatment. Table 4 summarizes all TEAEs deemed related to study drug by the site investigators. 
Table 4. Summary of related treatment-emergent adverse events (all randomized subjects)

\begin{tabular}{|c|c|c|c|c|c|}
\hline \multirow[t]{2}{*}{ System organ class preferred term } & \multirow{2}{*}{$\begin{array}{l}\text { Placebo, } \\
\mathrm{n}(\%) \\
(\mathrm{n}=31)\end{array}$} & \multicolumn{4}{|c|}{ MR calcifediol, n (\%) } \\
\hline & & $\begin{array}{l}30 \mu g \\
(n=13)\end{array}$ & $\begin{array}{l}60 \mu g \\
(n=17)\end{array}$ & $\begin{array}{l}90 \mu \mathrm{g} \\
(\mathrm{n}=17)\end{array}$ & $\begin{array}{l}\text { Total } \\
(\mathrm{n}=47)\end{array}$ \\
\hline Subjects with at least 1 drug-related TEAE & $5(16.1)$ & $2(15.4)$ & $4(23.5)$ & $4(23.0)$ & $10(21.2)$ \\
\hline Cardiac disorders & 0 & 0 & 0 & $1(5.9)$ & $1(2.1)$ \\
\hline Edema peripheral & 0 & 0 & 0 & $1(5.9)$ & $1(2.1)$ \\
\hline Gastrointestinal disorders & $4(12.9)$ & $2(15.4)$ & $1(5.9)$ & 0 & $3(6.4)$ \\
\hline Abdominal discomfort & 0 & $1(7.7)$ & 0 & 0 & $1(2.1)$ \\
\hline Abdominal distension & $1(3.2)$ & 0 & 0 & 0 & 0 \\
\hline Constipation & $1(3.2)$ & 0 & $1(5.9)$ & 0 & $1(2.1)$ \\
\hline Dry mouth & 0 & $1(7.7)$ & 0 & 0 & $1(2.1)$ \\
\hline General disorders and administration site conditions & 0 & $1(7.7)$ & $1(5.9)$ & 0 & $2(4.2)$ \\
\hline Fatigue & 0 & $1(7.7)$ & 0 & 0 & $1(2.1)$ \\
\hline Hot flush & 0 & 0 & $1(5.9)$ & 0 & $1(2.1)$ \\
\hline Investigations & $1(3.2)$ & 0 & 0 & $2(11.8)$ & $2(4.2)$ \\
\hline Blood LDH increased & $1(3.2)$ & 0 & 0 & 0 & 0 \\
\hline Vitamin D increased & 0 & 0 & 0 & $2(11.8)$ & $2(4.3)$ \\
\hline Metabolism and nutrition disorders & $1(3.2)$ & 0 & 0 & 0 & 0 \\
\hline Decreased appetite & $1(3.2)$ & 0 & 0 & 0 & 0 \\
\hline Musculoskeletal and connective tissue disorders & $1(3.2)$ & 0 & 0 & 0 & 0 \\
\hline Muscle spasms & $1(3.2)$ & 0 & 0 & 0 & 0 \\
\hline Pain in extremity & $1(3.2)$ & 0 & 0 & 0 & 0 \\
\hline
\end{tabular}

\section{Discussion}

Many studies have evaluated vitamin D (either cholecalciferol or ergocalciferol) as a treatment for vitamin D insufficiency or SHPT in adults with predialysis CKD [25-42]. Most were open-label studies and some were conducted in patients exhibiting SHPT. Only 9 were conducted with concurrent placebo or untreated control groups [34-42]. Vitamin D therapy produced modest or transient increases in serum 25-hydroxyvitamin D (generally $10-15 \mathrm{ng} / \mathrm{ml}$ ), leaving a considerable proportion of the treated patients (up to $50 \%$ ) showing no clinically meaningful increases in serum 25-hydroxyvitamin D or decreases in plasma iPTH. The overall conclusion from this body of work has been well summarized: 'Most of these studies have shown either no or minimal to inade- quate changes in PTH levels, usually only in some stages of $C K D$, or changes that still would not satisfy the K/DOQI recommended target ranges for $P T H^{\prime}$ [12].

Only three studies have evaluated calcifediol therapy in adults with stage 3 or 4 CKD and SHPT [43-45]. They showed IR calcifediol to be highly effective in raising serum 25 -hydroxyvitamin $\mathrm{D}$ but ineffective in reducing elevated PTH (by $\geq 30 \%$ from pre-treatment baseline) at doses that maintained mean serum 25 -hydroxyvitamin D between 30 and $100 \mathrm{ng} / \mathrm{ml}$, a range considered appropriate for CKD patients.

Data from the current study showed that a 6-week course of therapy with 30,60 or $90 \mu \mathrm{g} /$ day of MR calcifediol increased 25-hydroxyvitamin D levels to $\geq 30 \mathrm{ng} / \mathrm{ml}$ in more than $90 \%$ of subjects and reduced plasma iPTH by $\geq 30 \%$ from pre-treatment baseline in more than $60 \%$ 
of subjects at dosages $\geq 60 \mu \mathrm{g} /$ day. The mean 25 -hydroxyvitamin D level in the $30 \mu \mathrm{g}$ dose group at EOT was $37.3 \mathrm{ng} / \mathrm{ml}$, only modestly higher than the K/DOQI-specified minimum adequate level $(30 \mathrm{ng} / \mathrm{ml})$, indicating that this was the minimum effective dose for correcting vitamin D insufficiency. Mean 25-hydroxyvitamin D rose dose-responsively to $84.8 \mathrm{ng} / \mathrm{ml}$ in the $90 \mu$ g group, far higher than routinely achieved with ergocalciferol or cholecalciferol supplementation. The mean iPTH levels decreased in a similar fashion, reaching $39.3 \%$ below pretreatment baseline in the $90 \mu \mathrm{g}$ group and $56.5 \%$ below the pooled placebo group. The mean serum calcifediol did not quite reach steady-state levels during 6 weeks of treatment with MR calcifediol and, at EOT, had risen in the 60 and $90 \mu$ g groups to levels above $50 \mathrm{ng} / \mathrm{ml}$ for which the IOM has stated there 'may be reason for concern' [11]. Consequently, further research will focus on the 30 and $60 \mu \mathrm{g}$ doses and longer observation in larger numbers of CKD patients will be needed to establish the safety of these dose levels.

The pharmacodynamic effect of MR calcifediol on plasma iPTH coincided with increased exposures to calcifediol and serum total 1,25-dihydroxyvitamin $\mathrm{D}$. The iPTH reductions observed with 6 weeks of MR calcifediol therapy compared favorably to those previously observed in pre-dialysis patients during treatment with vitamin $\mathrm{D}$ hormone therapies. Doxercalciferol, for example, reduced the mean iPTH levels by approximately $30-32 \%$ after 12 weeks of treatment $[46,47]$. Paricalcitol produced a mean decrease in iPTH of about $29-52 \%$ after $12-24$ weeks [48-50]. Alfacalcidol treatment over 2 years produced no significant change in PTH from starting levels [51]. In the most recent study, calcitriol reduced the mean iPTH by $46 \%$ [50].

The safe upper limit for serum total 25-hydroxyvitamin $\mathrm{D}$ remains poorly defined in the general population and in patients with CKD. While the laboratory reference range is approximately 30 to $100 \mathrm{ng} / \mathrm{ml}$, the threshold for acute toxicity has been estimated at values above $100 \mathrm{ng} /$ $\mathrm{ml}$ [52], $150 \mathrm{ng} / \mathrm{ml}$ [53] and $>150-200 \mathrm{ng} / \mathrm{ml}[54,55]$. The threshold for long-term toxicity may be lower. The 2010 report by the IOM set the safe upper limit for serum 25 -hydroxyvitamin $\mathrm{D}$ at $30-48 \mathrm{ng} / \mathrm{ml}$ in healthy normal individuals, with levels of $50-60 \mathrm{ng} / \mathrm{ml}$ as the toxicity threshold [11]. This lower limit was based on observational studies of mortality in elderly subjects $[56,57]$ and in the general population [58] or on the incidence of cancer [59-61] and cardiovascular disease [62]. OPKO Health recently completed a carcinogenicity evaluation of calcifediol in a rodent model, as requested by the US Food

Modified-Release Calcifediol Suppresses $\mathrm{PTH}$ in CKD and Drug Administration, which showed no carcinogenicity potential at the highest dose tested $(33 \mu \mathrm{g} / \mathrm{kg} / \mathrm{day})$ [unpublished data]. Other studies cited in the same IOM report failed to support these lower ranges [63, 64]. Recent observational studies in CKD patients reported increased mortality with vitamin D insufficiency [65-70] suggesting that a higher serum 25 -hydroxyvitamin $\mathrm{D}$ is associated with improved clinical outcomes. As some authors have noted [27, 47], serum 25-hydroxyvitamin D levels of $30 \mathrm{ng} / \mathrm{ml}$ may not be adequate for PTH control in CKD patients, and the optimum level may be higher in $\mathrm{CKD}$ patients compared with the general population. The safety of serum total 25 -hydroxyvitamin $\mathrm{D}$ levels in the range of 30 to $100 \mathrm{ng} / \mathrm{ml}$ is being further investigated in ongoing larger and longer-term studies of MR calcifediol.

In conclusion, the present double-blinded placebocontrolled trial indicates that oral MR calcifediol administered in daily doses of 30,60 or $90 \mu \mathrm{g}$ is safe and highly effective in raising serum total 25 -hydroxyvitamin $\mathrm{D}$ concentrations to $\geq 30 \mathrm{ng} / \mathrm{ml}$ and reducing plasma iPTH concentrations in adult CKD patients with eGFRs ranging from approximately 20 to $70 \mathrm{ml} / \mathrm{min} / 1.73 \mathrm{~m}^{2}$. Additional trials with more prolonged periods of treatment are needed to define the long-term efficacy and safety of MR calcifediol as a vitamin D repletion therapy in CKD.

\section{Acknowledgments}

The authors thank Stephen A. Strugnell, PhD from Strugnell Consulting LLC, Madison, WI, for his assistance in preparing this manuscript for publication. They also thank the following clinical research sites for recruiting patients into the study: Southwest Houston Research (Houston, Tex., USA), Research by Design (Evergreen Park, Ill., USA), Denver Nephrologists (Denver, Colo., USA), Boise Kidney \& Hypertension Institute (Meridian, Idaho, USA), Pines Clinical Research (Pembroke Pines, Fla., USA), Twin Cities Clinical Research (Brooklyn Center, Minn., USA), Pharmax Research Clinic (Miami, Fla., USA), MetroHealth System (Cleveland, Ohio, USA), NorthShore University Health System (Evanston, Ill., USA), Dialysis Clinics (Cincinnati, Ohio, USA), Michigan Kidney Consultants (Pontiac, Mich., USA), AKDHC Medical Research Services (Phoenix, Ariz., USA), California Institute of Renal Research (La Mesa, Calif., USA), Research Management (Austin, Tex., USA), Renal Physicians of Georgia (Macon, Ga., USA) and Almeda Clinic (Houston, Tex., USA).

\section{Disclosure Statement}

Funding for this research was provided by Cytochroma Inc., acquired by OPKO Health, Inc. Dr. Sprague is an Associate Editor of AJN and a member of the Scientific Advisory Board for the OPKO Health Renal Division. 


\section{References}

1 US Renal Data System: USRDS 2013 Annual Data Report: Atlas of Chronic Kidney Disease and End-Stage Renal Disease in the United States, National Institutes of Health, National Institute of Diabetes and Digestive and Kidney Diseases, Bethesda, MD, 2013.

$\checkmark 2$ Gonzalez EA, Sachdeva A, Oliver DA, Martin $\mathrm{KJ}$ : Vitamin D insufficiency and deficiency in chronic kidney disease. A single center observational study. Am J Nephrol 2004;24:503510.

- 3 Levin A, Bakris GL, Molitch M, Smulders M, Tian J, Williams LA, Andress DL: Prevalence of abnormal serum vitamin $\mathrm{D}, \mathrm{PTH}$, calcium, and phosphorus in patients with chronic kidney disease: results of the study to evaluate early kidney disease. Kidney Int 2007;71:3138.

$\checkmark 4$ Helvig CF, Cuerrier D, Hosfield CM, Ireland B, Kharebov AZ, Kim JW, Ramjit NJ, Ryder K, Tabash SP, Herzenberg AM, Epps TM, Petkovich M: Dysregulation of renal vitamin D metabolism in the uremic rat. Kidney Int 2010;78:463-472.

5 Wolf M, Shah A, Gutierrez O, Ankers E, Monroy $\mathrm{M}$, Tamez $\mathrm{H}$, Steele D, Chang Y, Camargo CA Jr, Tonelli M, Thadhani R: Vitamin D levels and early mortality among incident hemodialysis patients. Kidney Int 2007;72:10041013.

-6 Dusso A, González EA, Martin KJ: Vitamin D in chronic kidney disease. Best Pract Res Clin Endocrinol Metab 2011;25:647-655.

-7 Zehnder D, Quinkler M, Eardley KS, Bland R, Lepenies J, Hughes SV, Raymond NT, Howie AJ, Cockwell P, Stewart PM, Hewison M: Reduction of the vitamin $\mathrm{D}$ hormonal system in kidney disease is associated with increased renal inflammation. Kidney Int 2008;74:13431353.

>8 Block GA, Ix JH, Ketteler M, Martin KJ, Thadhani RI, Tonelli M, Wolf M, Jüppner H, Hruska K, Wheeler DC: Phosphate homeostasis in CKD: report of a scientific symposium sponsored by the National Kidney Foundation. Am J Kidney Dis 2013;62:457473.

$\checkmark 9$ National Kidney Foundation: K/DOQI clinical practice guidelines for bone metabolism and disease in chronic kidney disease. Am J Kidney Dis 2003;42(4 suppl 3):S1-S201.

10 KDIGO clinical practice guideline for the diagnosis, evaluation, prevention, and treatment of Chronic Kidney Disease-Mineral and Bone Disorder (CKD-MBD). Kidney Int Suppl 2009;113:S1-S130.

11 Institute of Medicine: Dietary Reference Intakes for Calcium and Vitamin D. Washington, DC, The National Academies Press, 2010.

$\checkmark 12$ Kalantar-Zadeh K, Kovesdy CP: Clinical outcomes with active versus nutritional vitamin $\mathrm{D}$ compounds in chronic kidney disease. Clin J Am Soc Nephrol 2009;4:1529-1539.

-13 De Boer IH, Sachs M, Hoofnagle AN, Utzschneider KM, Kahn SE, Kestenbaum B,
Himmelfarb J: Paricalcitol does not improve glucose metabolism in patients with stage 3-4 chronic kidney disease. Kidney Int 2012;83: 323-330.

14 Sitrin MD, Pollack KL, Bolt MJ, Rosenberg $\mathrm{IH}$ : Comparison of vitamin D and 25-hydroxyvitamin D absorption in the rat. Am J Physiol 1982;242:G326-G332.

15 Leichtmann GA, Bengoa JM, Bolt MJ, Sitrin MD: Intestinal absorption of cholecalciferol and 25-hydroxycholecalciferol in patients with both Crohn's disease and intestinal resection. Am J Clin Nutr 1991;54:548-552.

16 Davies M, Mawer EB, Krawitt EL: Comparative absorption of vitamin D3 and 25-hydroxyvitamin D3 in intestinal disease. Gut 1980;21:287-292.

$>17$ Wagonfeld JB, Nemchausky BA, Bolt M, Horst JV, Boyer JL, Rosenberg IH: Comparison of vitamin D and 25-hydroxy-vitamin-D in the therapy of primary biliary cirrhosis. Lancet 1976;2:391-394.

18 Sitrin MD, Bengoa JM: Intestinal absorption of cholecalciferol and 25-hydroxycholecalciferol in chronic cholestatic liver disease. Am J Clin Nutr 1987;46:1011-1015.

19 Haldimann B, Healy M, Jelliffe R, Goldstein DA, Pattabhiraman R, Massry SG: Effect of an oral dose of 25-hydroxyvitamin $\mathrm{D}_{3}$ on its blood levels in patients with the nephrotic syndrome. J Clin Endocrinol Metab 1980;50:470-474.

20 Langman CB, Mazur AT, Baron R, Norman ME: 25-hydroxyvitamin D3 (calcifediol) therapy of juvenile renal osteodystrophy: beneficial effect on linear growth velocity. J Pediatr 1982;100:815-820.

21 Mazur AT, Norman ME: Effects of 25-OHD3 on renal function in pediatric patients with chronic renal failure. Miner Electrolyte Metab 1984; 10:351-358.

22 Petkovich M, Melnick J, White J, Tabash S, Strugnell S, Bishop CW: Modified release oral calcifediol corrects vitamin D insufficiency with minimal CYP24A1 upregulation. J Steroid Biochem Mol Biol 2014:http://dx.doi. org/10.1016/j.jsbmb.2014.11.1022.

23 Beck AT, Steer RA: Manual of the Revised Beck Depression Inventory. San Antonio, TX, USA, Pearson Education, 1987.

24 Levey AS, Coresh J, Greene T, Stevens LA, Zhang YL, Hendriksen S, Kusek JW, Van Lente F: Using standardized serum creatinine values in the modification of diet in renal disease study equation for estimating glomerular filtration rate. Ann Intern Med 2006;145: 247-254.

25 DeVille J, Thorp ML, Tobin L, Gray E, Johnson ES, Smith DH: Effect of ergocalciferol supplementation on serum parathyroid hormone and serum 25-hydroxyvitamin $\mathrm{D}$ in chronic kidney disease. Nephrology (Carlton) 2006;11:555-559.

26 Al-Aly Z, Qazi RA, Gonzalez EA, et al: Changes in serum 25-hydroxyvitamin $\mathrm{D}$ and plasma intact PTH levels following treatment with er- gocalciferol in patients with CKD. Am J Kidney Dis 2007;50:59-68.

27 Zisman AL, Hristova M, Ho LT, Sprague SM: Impact of ergocalciferol treatment of vitamin D deficiency on serum parathyroid hormone concentrations in chronic kidney disease. Am J Nephrol 2007;27:36-43.

28 Oksa A, Spustova V, Krivosikova Z, Gazdíková K, Fedelesová V, Lajdová I, Stefíková K, Bernasovská G, Zilinská Z, Dzúrik R: Effects of long-term cholecalciferol supplementation on mineral metabolism and calciotropic hormones in chronic kidney disease. Kidney Blood Press Res 2008;31:322-329.

29 Lajdova I, Spustova V, Oksa A, Chorvatova A, Chorvat D Jr, Dzurik R: Intracellular calcium homeostasis in patients with early stages of chronic kidney disease: effects of vitamin D3 supplementation. Nephrol Dial Transplant 2009;24:3376-3381.

- 30 Trakarnvanich T, Chalapipat O, Disthabanchong S, Kurathong S, Praditpornsilpa K, Stitchantrakul W, Chailurkit LO: Effect of high dose ergocalciferol in chronic kidney disease patients with 25-hydroxyvitamin D deficiency. J Med Assoc Thai 2010;93:885-891.

31 Kim MJ, Frankel AH, Donaldson M, Darch SJ, Pusey CD, Hill PD, Mayr M, Tam FW: Oral cholecalciferol decreases albuminuria and urinary TGF- $\beta 1$ in patients with type 2 diabetic nephropathy on established reninangiotensin-aldosterone system inhibition. Kidney Int 2011;80:851-860.

-32 Taskapan H, Baysal O, Karahan D, Durmus B, Altay Z, Ulutas O: Vitamin D and muscle strength, functional ability and balance in peritoneal dialysis patients with vitamin $\mathrm{D}$ deficiency. Clin Nephrol 2011;76:110-116.

33 Garcia-Lopes MG, Pillar R, Kamimura MA, Rocha LA, Canziani ME, Carvalho AB, Cuppari L: Cholecalciferol supplementation in chronic kidney disease: restoration of vitamin D status and impact on parathyroid hormone. Ann Nutr Metab 2012;61:74-82.

34 Chandra P, Binongo JN, Ziegler TR, Schlanger LE, Wang W, Someren JT, Tangpricha V: Cholecalciferol (vitamin D3) therapy and vitamin D insufficiency in patients with chronic kidney disease: a randomized controlled pilot study. Endocr Pract 2008;14:10-17.

35 Dogan E, Erkoc R, Sayarlioglu H, Soyoral Y, Dulger H: Effect of depot oral cholecalciferol treatment on secondary hyperparathyroidism in stage 3 and stage 4 chronic kidney diseases patients. Ren Fail 2008;30:407-410.

36 Kooienga L, Fried L, Scragg R, Kendrick J, Smits G, Chonchol M: The effect of combined calcium and vitamin D3 supplementation on serum intact parathyroid hormone in moderate CKD. Am J Kidney Dis 2009;53:408-416.

-37 Rucker D, Tonelli M, Coles MG, Yoo S, Young K, McMahon AW: Vitamin D insufficiency and treatment with oral vitamin D3 in northern-dwelling patients with chronic kidney disease. J Nephrol 2009;22:75-82. 
38 Basturk T, Unsal A, Ulas T: Effect of cholecalciferol on parathyroid hormone and vitamin D levels in chronic kidney disease. Minerva Urol Nefrol 2011;63:287-292.

-39 Alvarez JA, Law J, Coakley KE, Zughaier SM, Hao L, Shahid Salles K, Wasse H, Gutiérrez OM, Ziegler TR, Tangpricha V: High-dose cholecalciferol reduces parathyroid hormone in patients with early chronic kidney disease: a pilot, randomized, double-blind, placebocontrolled trial. Am J Clin Nutr 2012;96:672679.

-40 Marckmann P, Agerskov H, Thineshkumar S, Bladbjerg EM, Sidelmann JJ, Jespersen J, Nybo M, Rasmussen LM, Hansen D, Scholze A: Randomized controlled trial of cholecalciferol supplementation in chronic kidney disease patients with hypovitaminosis D. Nephrol Dial Transplant 2012;27:3523-3531.

-41 Gravesen E, Hofman-Bang J, Lewin E, Olgaard K: Ergocalciferol treatment and aspects of mineral homeostasis in patients with chronic kidney disease stage $4-5$. Scand J Clin Lab Invest 2013;73:107-116.

-42 Petchey WG, Hickman IJ, Prins JB, Hawley CM, Johnson DW, Isbel NM: Vitamin D does not improve the metabolic health of patients with chronic kidney disease stage 3-4: a randomized controlled trial. Nephrology (Carlton) 2013;18:26-35.

-43 Saab G, Young DO, Gincherman Y, Giles K, Norwood K, Coyne DW: Prevalence of vitamin $\mathrm{D}$ deficiency and the safety and effectiveness of monthly ergocalciferol in hemodialysis patients. Nephron Clin Pract 2007; 105:c132-c138.

44 Bordier PJ, Marie PJ, Arnaud CD: Evolution of renal osteodystrophy: correlation of bone histomorphometry and serum mineral and immunoreactive parathyroid hormone values before and after treatment with calcium carbonate or 25-hydroxycholecalciferol. Kidney Int Suppl 1975;2:102-112.

45 Letteri JM, Kleinman LM, Ellis KN, Caselnova R, Akhtar M, Cohn SH: Effects of 25-hydroxycholecalciferol on calcium metabolism in chronic renal failure. Adv Exp Med Biol 1977;81:591-601.

46 Fournier A, Idrissi A, Sebert JL, Gueris J, Garabedian M, Renaud H, Westeel PF: Preventing renal bone disease in moderate renal failure with $\mathrm{CaCO} 3$ and $25(\mathrm{OH})$ vitamin $\mathrm{D} 3$. Kidney Int Suppl 1988;24:S178-S179.

47 Moe SM, Saifullah A, LaClair RE, Usman SA, Yu Z: A randomized trial of cholecalciferol versus doxercalciferol for lowering parathyroid hormone in chronic kidney disease. Clin J Am Soc Nephrol 2010;5:299-306.
48 Coburn JW, Maung HM, Elangovan L, Germain MJ, Lindberg JS, Sprague SM, Williams ME, Bishop CW: Doxercalciferol safely suppresses PTH levels in patients with secondary hyperparathyroidism associated with chronic kidney disease stages 3 and 4. Am J Kidney Dis 2004;43:877-890.

49 Kovesdy CP, Lu JL, Malakauskas SM, Andress DL, Kalantar-Zadeh K, Ahmadzadeh S: Paricalcitol versus ergocalciferol for secondary hyperparathyroidism in CKD stages 3 and 4: a randomized controlled trial. Am J Kidney Dis 2012;59:58-66.

50 Coyne D, Acharya M, Qiu P, Abboud H, Batlle D, Rosansky S, Fadem S, Levine B, Williams L, Andress DL, Sprague SM: Paricalcitol capsule for the treatment of secondary hyperparathyroidism in stages 3 and 4 CKD. Am J Kidney Dis 2006;47:263-276.

51 Coyne DW, Goldberg S, Faber M, Ghossein C, Sprague SM: A randomized multicenter trial of paricalcitol versus calcitriol for secondary hyperparathyroidism in stages 3-4 CKD. Clin J Am Soc Nephrol 2014;9:1620-1626.

52 Hamdy NA, Kanis JA, Beneton MN, Brown CB, Juttmann JR, Jordans JG, Josse S, Meyrier A, Lins RL, Fairey IT: Effect of alfacalcidol on natural course of renal bone disease in mild to moderate renal failure. BMJ 1995;310:358-363.

53 Hollis BW: Circulating 25-hydroxyvitamin D levels indicative of vitamin D sufficiency: implications for establishing a new effective dietary intake recommendation for vitamin $\mathrm{D}$. J Nutr 2005; 135:317-322.

54 Holick MF: Vitamin D for health and in chronic kidney disease. Semin Dial 2005;18: 266-275.

55 Jones G: Interpreting vitamin D assay results: proceed with caution. Clin J Am Soc Nephrol 2014;pii:CJN.05490614, Epub ahead of print.

56 Jones G: Pharmacokinetics of vitamin D toxicity. Am J Clin Nutr 2008;88:582S-586S

57 Visser M, Deeg DJ, Puts MT, Seidell JC, Lips P: Low serum concentrations of 25-hydroxyvitamin $\mathrm{D}$ in older persons and the risk of nursing home admission. Am J Clin Nutr 2006;84:616-622

58 Jia X, Aucott LS, McNeill G: Nutritional status and subsequent all-cause mortality in men and women aged 75 years or over living in the community. Br J Nutr 2007;98:593-599.

59 Melamed ML, Michos ED, Post W, Astor B: 25-hydroxyvitamin D levels and the risk of mortality in the general population. Arch Intern Med 2008;168:1629-1637.

60 Chlebowski RT, Johnson KC, Kooperberg C, Pettinger M, Wactawski-Wende J, Rohan T, Rossouw J, Lane D, O'Sullivan MJ, Yasmeen S, Hiatt RA, Shikany JM, Vitolins M, Khandekar J, Hubbell FA: Calcium plus vitamin D supplementation and the risk of breast cancer. J Natl Cancer Inst 2008;100:1581-1591.
61 Stolzenberg-Solomon RZ, Jacobs EJ, Arslan AA, Qi D, Patel AV, Helzlsouer KJ, Weinstein SJ, McCullough ML, Purdue MP, Shu XO, Snyder K, Virtamo J, Wilkins LR, Yu K, Zeleniuch-Jacquotte A, Zheng W, Albanes D, Cai Q, Harvey C, Hayes R, Clipp S, Horst RL, Irish L, Koenig K, Le Marchand L, Kolonel LN: Circulating 25-hydroxyvitamin D and risk of pancreatic cancer: Cohort Consortium Vitamin D Pooling Project of Rarer Cancers. Am J Epidemiol 2010;172:81-93.

62 Tuohimaa P, Tenkanen L, Ahonen M, Lumme S, Jellum E, Hallmans G, Stattin P, Harvei S, Hakulinen T, Luostarinen T, Dillner J, Lehtinen M, Hakama M: Both high and low levels of blood vitamin $\mathrm{D}$ are associated with a higher prostate cancer risk: a longitudinal, nested case-control study in the Nordic countries. Int J Cancer 2004;108:104-108.

63 Ginde AA, Scragg R, Schwartz RS, Camargo CA Jr: Prospective study of serum 25-hydroxyvitamin D level, cardiovascular disease mortality, and all-cause mortality in older U.S. adults. J Am Geriatr Soc 2009;57:1595-1603.

64 Sambrook PN, Chen CJ, March L, Cameron ID, Cumming RG, Lord SR, Simpson JM, Seibel MJ: High bone turnover is an independent predictor of mortality in the frail elderly. J Bone Miner Res 2006;21:549-555.

65 Giovannucci E, Liu Y, Willett WC: Cancer incidence and mortality and vitamin $\mathrm{D}$ in black and white male health professionals. Cancer Epidemiol Biomarkers Prev 2006;15:24672472.

66 Ravani P, Malberti F, Tripepi G, Pecchini P, Cutrupi S, Pizzini P, Mallamaci F, Zoccali C: Vitamin D levels and patient outcome in chronic kidney disease. Kidney Int 2009;75: 88-95.

67 de Boer IH, Katz R, Chonchol M, Ix JH, Sarnak MJ, Shlipak MG, Siscovick DS, Kestenbaum B: Serum 25-hydroxyvitamin D and change in estimated glomerular filtration rate. Clin J Am Soc Nephrol 2011;6:2141-2149.

68 Pilz S, Iodice S, Zittermann A, Grant WB, Gandini S: Vitamin D status and mortality risk in CKD: a meta-analysis of prospective studies. Am J Kidney Dis 2011;58:374-382.

69 Mehrotra R, Kermah DA, Salusky IB, Wolf MS, Thadhani RI, Chiu YW, Martins D, Adler SG, Norris KC: Chronic kidney disease, hypovitaminosis $\mathrm{D}$, and mortality in the United States. Kidney Int 2009;76:977-983.

-70 Navaneethan SD, Schold JD, Arrigain S, Jolly SE, Jain A, Schreiber MJ Jr, Simon JF, Srinivas TR, Nally JV Jr: Low 25-hydroxyvitamin D levels and mortality in non-dialysis-dependent CKD. Am J Kidney Dis 2011;58:536-543. 